\title{
IT Master Plan
}

\section{Pedoman Penyusunan dan Implementasi}

\author{
Iwan Prasetiawan \\ Fakultas Teknik \& Informatika, Universitas Multimedia Nusantara, Tangerang, Indonesia. \\ iwan.prasetiawan@lecturer.umn.ac.id \\ Diterima 6 Agustus 2018 \\ Disetujui 24 Juni 2019
}

\begin{abstract}
The rapid development of business, supported by technological developments that are not less rapid, it requires a strong and precise alignment between business strategies or organizations with the Information Systems (IS) strategy and Information Technology (IT) strategies as supporters. An IT strategy plan includes many aspects, covering several aspects which include aspects of technology architecture, roadmap / work plan, and supporting standards for its implementation. This Guidelines for Preparation and Implementation of the IT Master Plan, explains the methods and main steps in managing and implementing IT strategy to support the implementation of the main tasks and the achievement of the strategic objectives of an organization or company. An important aspect that concern to the author is the importance of organizational and management involvement. Which is a key aspect of the planning process, together to ensure that all IS components have the same goals and direction as the business so it is easy to identify organizations that have not aligned. The logical relationship between business strategy and IT strategy does not usually occur directly, but through an intermediary for determining the IS Strategy, the strategy must be able to translate business strategies into the perspective of data and information flow to finally determine the information and communication technology work plan up to the specified year compiled in an IT Master Plan.
\end{abstract}

Index Terms - Information Systems, Information Technology, IT Strategy, IT Master Plan

\section{Pendahuluan}

Dokumen IT Master Plan merupakan uraian rencana strategi Teknologi Informasi (TI) secara rinci yang meliputi banyak aspek, termasuk di dalamnya adalah aspek-aspek arsitektur teknologi, roadmap/ rencana kerja untuk implementasinya, serta standarstandar pendukungnya ${ }^{1}$.

TI di-implementasikan sebagai alat bantu organisasi atau perusahaan mencapai visi dan misinya. Maka, tanpa ada visi dan misi yang jelas dari perusahaan, maka IT Master Plan juga tidak bisa dibangun. ${ }^{[1]}$ IT master plan menjadi dasar bagi perencanaan perusahaan dalam melakukan investasi dan implementasi TI. Dengan demikian, perusahaan tidak lagi sekadar beli ataupun instal, tetapi mempunyai perencanaan yang baik dan perusahaan bisa mengurangi berbagai risiko yang mungkin timbul dalam implementasi TI. ${ }^{[1]}$

Mengutip pernyataan yang disampaikan oleh Lembaga Riset Telematika Sharingvision ${ }^{2}$ bahwa, masih terdapat beberapa kelemahan-kelemahan pengembangan Master Plan TI di Indonesia seperti :

1) Strategi informasi dan master plan TI yang ternyata kurang implementable,

2) Kurang mempertimbangkan aspek kelemahan kondisi lokal, baik kelemahan infrastruktur telekomunikasi maupun kurangnya kompetensi SDM diperusahaan,

3) Kurang mendalam saat meng-capture kebutuhan TI Perusahaan. ${ }^{[2]}$

Dengan latar belakang pernyataan tersebut diatas, maka Penulis ingin menyampaikan ide hasil dari pemikiran dan pengalaman berupa pedoman praktis untuk penyusunan dan implementasi Master Plan TI yang diharapkan menjadi salah satu solusi terhadap kelemahan-kelemahan pengembangan Master Plan TI di Indonesia.

Proses penyusunan IT Master Plan pada tulisan tersebut ini menggunakan beberapa referensi ${ }^{[1][2][3][4]}$ pengembangan strategi teknologi informasi yang disederhanakan serta mudah dilakukan dan efektif melalui 2 (dua) tahapan proses, yaitu proses penyusunan dan proses implementasi IT Master Plan. 


\section{Metodologi Penyusunan IT Master Plan}

Metodologi penyusunan IT Master Plan mendeskripsikan serangkaian kegiatan yang memiliki hubungan dan hasil keluaran yang jelas dan terukur.Beberapa metologi penyusunan IT Master Plan yang penulis gunakan sebagai referensi adalah sebagai berikut:

a) Metodologi 'IT-Plan Universitas Indonesia' oleh Arrianto Mukti Wibowo dan Budi Yuwono ${ }^{[3]}$ dipergunakan untuk menghasilkan cetak biru/ blueprint dan strategi TIK/ Teknologi Informasi dan Komunikasi seperti dijelaskan pada gambar 1 dibawah ini,

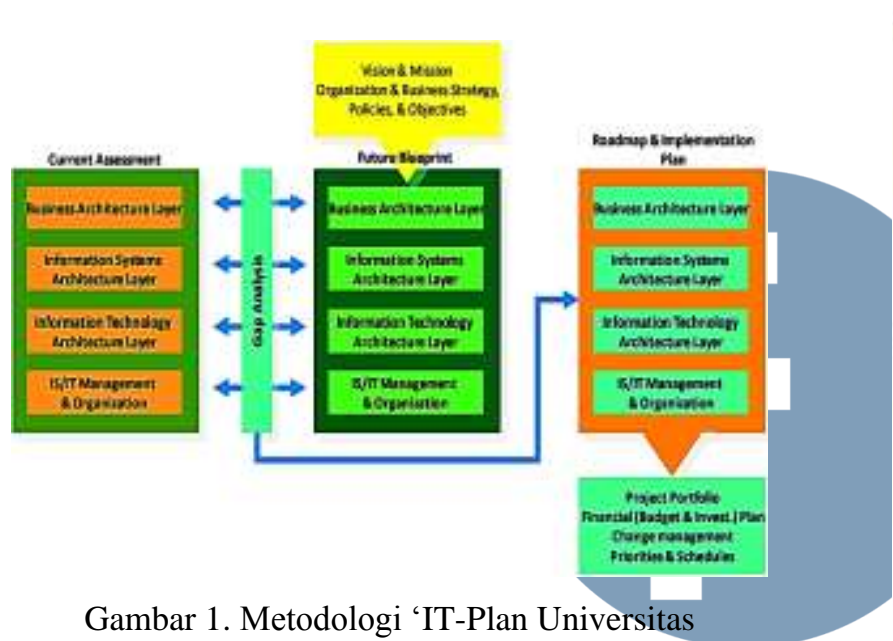
Indonesia' ${ }^{[3]}$

Proses penyusunannya dimulai dengan tahapan penilaian/ assessment keadaan saat ini, kemudian proses penyusunan visi, misi dan strategi, dan dilanjutkan dengan menetapkan rencana pekerjaan akan datang/ blueprint. Selanjutnya dilakukan analisa kesenjangan antara keadaan saat ini dengan kebutuhan akan datang, yang pada akhirnya menjadi dasar dalam menyusun roadmap dan rencana implementasi. Pada bagian akhir ini dapat disusun rencana program kerja serta portofolio proyek.

b) Metodologi Penyusunan Master Plan Pengembangan Sistem dan Teknologi Informasi oleh Prof. Richardus Eko Indrajit ${ }^{[4]}$, dengan prinsip bahwa terdapat 5 (lima) domain tahapan konsep penyusunan IT master plan yang dimaksud yaitu:

a. Kajian Profil dan Strategi Organisasi

b. Analisa Kebutuhan Sistem Informasi

c. Penentuan Spesifikasi Teknologi Informasi

d. Manajemen Portofolio Program dan Proyek

e. Pengelolaan Tata Pamong Sistem Informasi
Kelima tahapan tersebut merupakan langkahlangkah sekuensial yang biasa dipergunakan dalam menyusun sebuah master plan seperti dijelaskan secara rinci pekerjaan di masingmasing tahapan tersebut pada gambar 2 Metodologi dan Penyusunan Master Plan Pengembangan Sistem dan Teknologi Informasi:

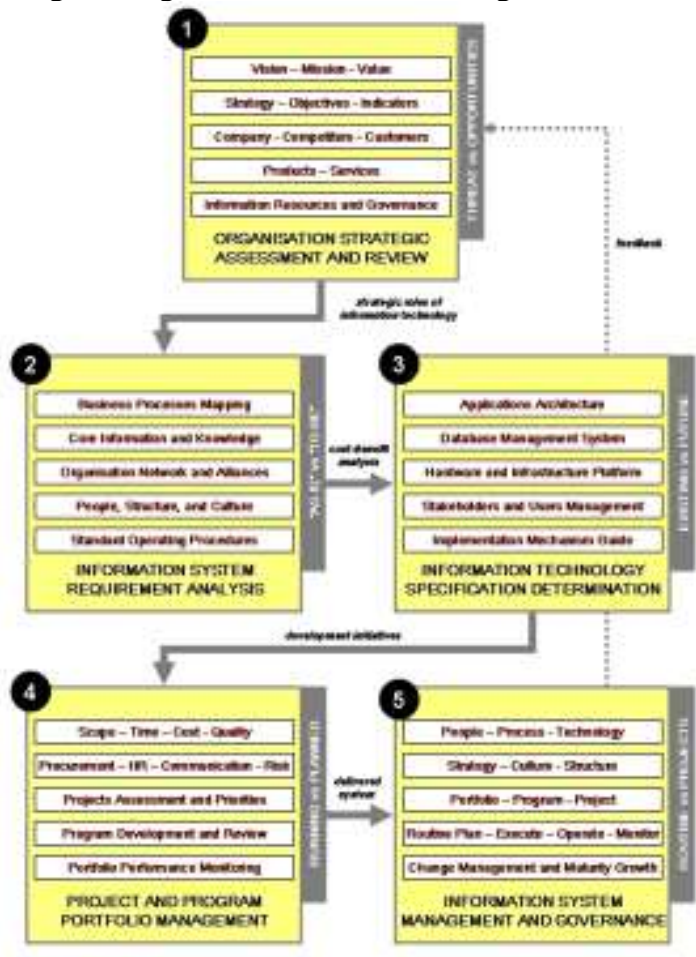

Gambar 2. Metodologi Penyusunan Master Plan Pengembangan Sistem dan Teknologi Informasi $^{[4]}$

Berdasarkan 2 (dua) buah referensi metodologi penyusunan IT Master Plan tersebut diatas, penulis merangkum tahapan pekerjaannya menjadi 2 (dua) domain tahapan konsep penyusunannya yaitu: Perencanaan dan Implementasi IT Master Plan.

\section{PERENCANAAN IT MASTER PLAN}

\section{A. Perencanaan Awal Strategi Teknologi Informasi}

Strategi TI yang efektif akan membantu organisasi atau perusahaan untuk merasakan manfaat nyata yang diberikan seperti : ${ }^{[5]}$

1) Strategi TI yang sukses memastikan keselarasan organisasi atau perusahaan dan TI pada skala strategis. Implementasi TI yang sesuai dengan kepentingan dan kebutuhan organisasi atau perusahaan serta menghindari pemborosan anggaran untuk hal-hal yang tidak penting bagi organisasi atau perusahaan.

2) Arah dan keputusan investasi TI yang informatif dalam skala strategis. Strategi TI yang berhasil memberikan gambaran yang jelas tentang bagaimana masing-masing investasi TI yang direncanakan mendukung tujuan organisasi atau perusahaan dengan mengatasi kesenjangan yang 
diidentifikasi antara keadaan saat ini dan keadaan yang akan dicapai oleh TI.

Sehingga selanjutnya akan didapatkan strategi TI yang memberikan nilai/ manfaat yang dapat menghindari pengeluaran dan investasi TI yang tidak selaras serta menghindari serta mewujudkan dukungan TI yang sebelumnya tidak mendukung tujuan organisasi atau perusahaan seperti dijelaskan pada gambar 3 mengenai Nilai dan Manfaat TI dibawah ini,

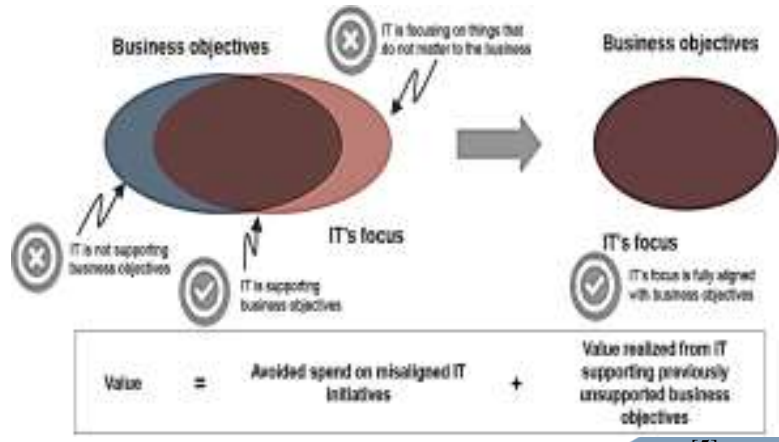

Gambar 3. Nilai dan Manfaat Strategi $\mathrm{TI}^{[5]}$

Langkah awal untuk strategi TI dapat memberikan nilai dan manfaat tersebut diatas, adalah melakukan proses assessment atau penggalian informasi terhadap kondisi saat ini yang telah ada dan dilaksanakan saat ini. Penggalian informasi ini dilakukan melalui proses analisis bisnis yang meliputi :

- Arsitektur aplikasi,

- Arsitektur infrastruktur, dan

- Arsitektur organisasi.

Pada arsitektur aplikasi akan digambarkan tujuan penggunaan aplikasi untuk mendukung bisnis oganisasi secara integrasi untuk memproses data dan konteks dimana aplikasi tersebut beroperasi. Penggambaran infrastruktur teknologi informasi adalah dalam rangka mendukung informasi dan aplikasi akan diproses di arsitektur infrastruktur, sedangkan arsitektur organisasi akan menggambarkan aspek manajemen teknologi informasi untuk mendukung implementasi TI di organisasi.

Strategi Teknologi Informasi dalam suatu organisasi merupakan inisiatif-inisiatif atau langkahlangkah pada tingkat abstraksi yang relatif tinggi yang menyatakan hal-hal yang dapat dilakukan untuk mencapai tujuan organisasi melalui pemberdayaan sumber daya Teknologi Informasi.

Proses selanjutnya adalah melakukan analisis terhadap Gap/ Kesenjangan dan Skala prioritas terhadap kondisi saat ini dengan kondisi yang diharapkan oleh perusahaan.

Skala prioritas tersebut dituangkan kedalam IT Initiative yang akan dijalankan nantinya dan disusun dalam sebuah rencana kerja/ roadmap IT Master Plan yang akan menjadi patokan atau panduan proses bisnis dan teknologi dalam jangka waktu tertentu 3-5 tahun ke depan.
Proses assessment yang terakhir dilakukan adalah analisis strategi pendanaan dan strategi implementasi dan pengukuran /framework yang disesuaikan dengan kemampuan perusahaan

\section{B. Hubungan Strategi Teknologi Informasi dan Strategi Bisnis}

Strategi bisnis perusahaan merupakan acuan utama dalam membangun strategi Teknologi Informasi. Strategi bisnis atau strategi biasanya ditentukan oleh visi dan misi perusahaan.

Hubungan logika antara strategi bisnis dengan strategi Teknologi Informasi biasanya tidak terjadi secara langsung, tetapi melalui suatu perantaraan dan penentuan Strategi Sistem Informasi, seperti dijelaskan pada bagan alur Hubungan antara Bisnis, SI dan TI pada gambar 4 dibawah ini:

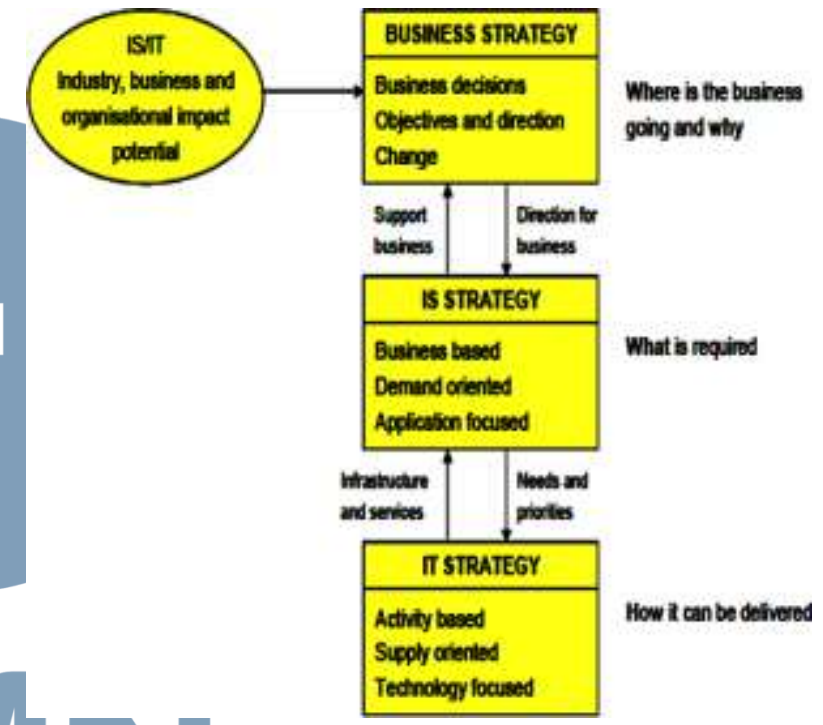

Gambar 4. Hubungan antara Bisnis, Sistem Informasi dan Teknologi Informasi ${ }^{[6]}$

Strategi organisasi menentukan kemana arah organisasi dan mengapa harus menuju kesana. Strategi tersebut akan menjadi referensi untuk menentukan Strategi Informasi, yang harus menterjemahkan strategi bisnis menjadi perspektif aliran data dan informasi sampai akhirnya dapat menentukan rencana kerja/ roadmap Teknologi Informasi dan komunikasi sampai pada tahun yang ditentukan.

Penerjemahan peran Sistem Informasi dan Teknologi Informasi dalam keselarasan bisnis, pada prinsipnya adalah Strategi Teknologi Informasi yang dituntut untuk menyediakan informasi yang dibutuhkan oleh bisnis dengan tujuan agar tercapainya objektifitas bisnis, yang mana proses tersebut merupakan pendefinisian dari tujuan dan strategi teknologi informasi yang selaras dengan tujuan organisasi atau perusahaan pada skala strategis serta implementasi dan pemanfaatan TI yang efektif dan efisien. 


\section{Strategi Sisem Informasi}

Pendekatan strategi SI harus mencerminkan cara pendekatan perencanaan bisnis, jika pendekatan perencanaan bisnis lebih terpusat, maka seharusnya pendekatan strategi SI direncancakan untuk terpusat.

Perencanaan strategi Sistem Informasi (SI) adalah dalam rangka memberikan nilai tambah bagi organisasi dengan beberapa kriteria sebagai berikut :

- Meningkatkan pengelolaan aset SI,

- Meningkatkan komunikasi antara departemen bisnis dan SI,

- Menyelaraskan arahan Strategi SI dengan bisnis,

- Memberikan peluang bisnis dan meningkatkan nilai ke bisnis,

- Merencanakan alur informasi dan proses SI,

- Secara efisien dan efektif mengalokasikan sumber daya SI.

Perencanaan strategi SI adalah komponen kunci untuk keberhasilan fungsi SI dan merupakan faktor penting dalam membantu perusahaan dalam mencapai tujuan bisnisnya, seperti yang ditunjukkan pada Gambar 5 mengenai peranan penting strategi SI untuk bisnis dibawah ini:
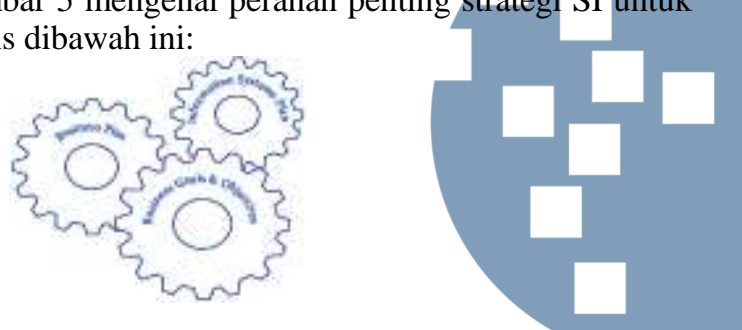

Gambar 5. Peranan penting Strategi SI untuk bisnis ${ }^{[7]}$
Selanjutnya, dijelaskan mengenai keselarasan Strategi SI dengan bisnis pada Gambar 7, keselarasan dan korelasi yang berbeda harus dapat terlihat jelas saat meninjau setiap bagian dari rencana bisnis perusahaan dan rencana SI. Semua komponen SI harus memiliki tujuan dan arah yang sama dengan bisnis sehingga sangat mudah untuk mengidentifikasi organisasi yang belum mencapai keselarasan, sebagai contoh gejala buruk yamg terjadi dari keselarasan SI dan bisnis adalah : proyek implementasi SI yang dibatalkan atau proyek implementasi SI yang redundan.

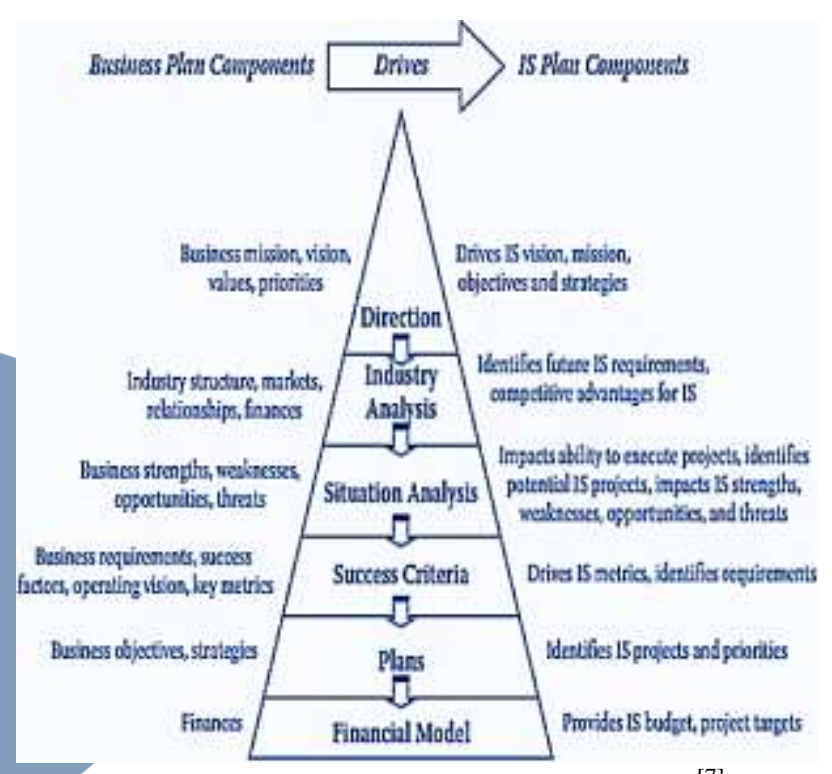

Gambar 7. Strategi SI selaras dengan bisnis ${ }^{[7]}$
Keselarahan SI dengan bisnis merupakan perjuangan dan tantangan bagi organisasi untuk mencapai keselarasan efektif. Keselarasan yang efektif terjadi ketika semua kegiatan SI memberikan dukungan optimal untuk tujuan, sasaran dan strategi bisnis, sehingga SI dan bisnis berjalan selaras.

Oganisasi harus mengintegrasikan SI dengan bisnis dalam hubungan simbiosis. Seperti yang ditunjukkan pada Gambar 6 berikut, bahwa komponen-komponen SI yang diintegrasikan meliputi : strategi, organisasi, proses, infrastruktur, aplikasi, proyek, anggaran, dan ukurannya harus mencerminkan keselarasan dengan bisnis.
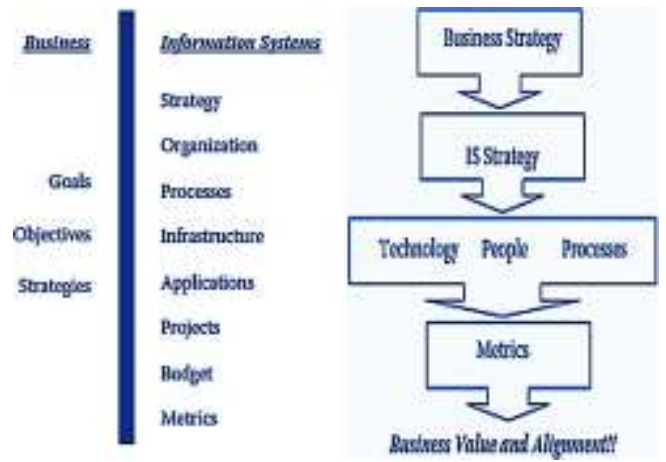

Gambar 6. Komponen keselarasan SI dan nilai bisnis $^{[7]}$

\section{Keterlibatan Organisasi}

Bagaimana perusahaan dapat memastikan komitmen terhadap rencana strategis? rencana tersebut harus mencerminkan ide manajemen, gaya, dan tujuan. Agar berhasil maka, seluruh organisasi harus mendukung tujuan SI/ Sistem Informasi dan faktor terbesar untuk strategi yang sukses adalah keterlibatan organisasi dan manajemen.

Komunikasi dan keterlibatan manajemen adalah aspek kunci dari proses perencanaan. Proses perencanaan adalah terdiri dari $80 \%$ komunikasi untuk mendapatkan masukan dan evaluasi, dan $20 \%$ merupakan perencanaan.

Hal umum yang seringkali terjadi adalah kendala untuk mendapatkan keterlibatan dan komitmen dari manajemen, sehingga dapat dibayangkan bagaimana sulitnya organisasi dapat memastikan rencana startegis yang berkelanjutan sehingga kerapkali terjadi kegagalan implementasi dari IT Master Plan yang sudah ditetapkan organisasi.

Proses perencanaan strategis harus dimulai dengan melibatkan semua tingkat bisnis organisasi dalam proses perencanaan dan tata kelola/ governance. Bila perlu tedapat kebutuhan untuk membentuk beberapa kelompok perencanaan untuk melibatkan berbagai tingkatan organisasi dalam pengembangan rencana 
awal dan tata kelola yang berkelanjutan seperti digambarkan pada bagan keterlibatan organisasi pada gambar 8 dibawah ini:

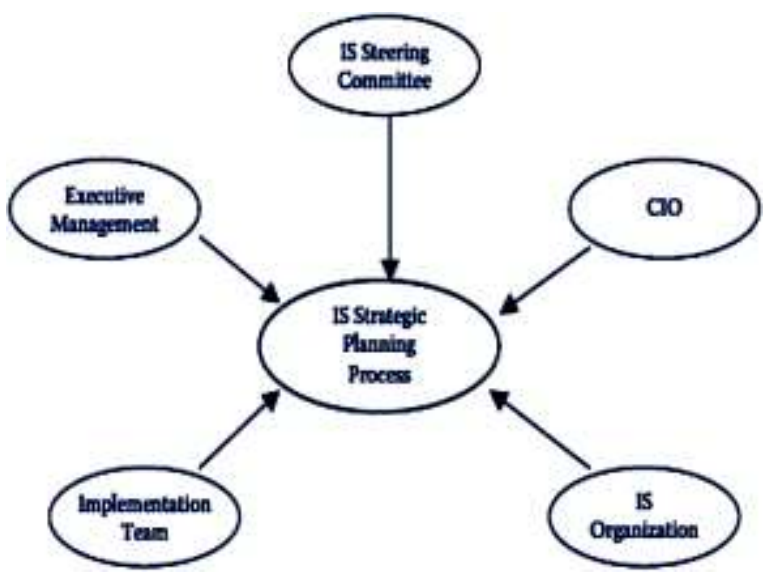

Gambar 8. Keterlibatan Organisasi ${ }^{[7]}$

Dengan uraian tugas dan tanggung jawab dari masingmasing kelompok tersebut diatas adalah sebagai berikut:

\section{Executive management}

Merupakan pelaksanaan manajemen berjenjang / struktural yang memberikan arahan dan prioritas bisnis yang strategis serta menyetujui arah rencana dan strategis SI dan memberikan otoritas final dalam alokasi sumber daya termasuk anggaran SI.

IS steering committee

Kelompok ini terdiri dari pelbagai pimpinan yang mewakili bisnis dan SI yang akan merumuskan rekomendasi mengenai prioritas proyek dan sumber daya dan menyediakan masukan ke arah strategis SI dan memastikan pihak Bisnis berkomitmen untuk memberikan manfaat bisnis dari proyek SI yang diselenggarakan.

\section{CIO/ Chief Information officer}

CIO mengkoordinasikan dan mengarahkan keterlibatan dari seluruh organisasi dalam proses perencanaan strategis serta mengomunikasikan rencana dengan jelas sehingga seluruh organisasi memahami dengan baik.

\section{IS organization}

Merupakan organisasi pengelola Sistem dan Teknologi Informasi yang harus berkomitmen untuk merencanakan proyek implementasinya dalam biaya dan tanggal yang sudah dianggarkan

\section{Implementation team}

Komposisi tim implementasi harus menyertakan perwakilan dari area bisnis yang terkena dampak perubahan, serta satu atau dua individu dari organisasi SI untuk bersama-sama mempersiapkan dan menerapkan sistem baru atau peningkatan bisnis proses.

Dokumentasikan peran dan tanggung jawab masing-masing kelompok yang terlibat dalam proses tata kelola organisasi sehingga otoritas pengambilan keputusan menjadi jelas. Sangat penting untuk dapat menentukan siapa yang akan bertanggung jawab, memberikan masukan dan membuat keputusan yang terlibat dalam proses perencanaan strategis bahkan sebelum proses perencanaan strategis dimulai.

\section{IMPLEMENTASI IT MASTER PLAN}

Rencana strategis organisasi yang sudah selaras antara strategi bisnis dan strategi Sistem Informasi (SI) disusun kedalam sebuah dokumentasi IT Master Plan. Selanjutnya dirincikan kedalam beberapa proyek implementasi SI yang saling berkaitan, dan masingmasing proyek dapat dikelola secara terpisah, akan tetapi akan dikoordinasikan secara erat untuk memastikan bahwa ketergantungan antar proyek serta teknologi informasi dan standar data yang diimplementasikan teridentifikasi dengan baik.

Implementasi IT Master Plan adalah istilah yang digunakan untuk menggambarkan proses atau kegiatan yang memastikan perencanaan strategis benar-benar siap dan layak untuk diimplementasikan.

Untuk memudahkan pelaksanaannya, penulis menggunakan langkah-langkah proses perencanaan strategi SI melalui penyelarasan terhadap strategi bisnis organisasi Metode Anita Cassidy yang terdiri dari 4 fase yaitu fase-fase : visioning, analysis, direction, dan recommendation seperti diuraikan pada gambar 9 dibawah ini:

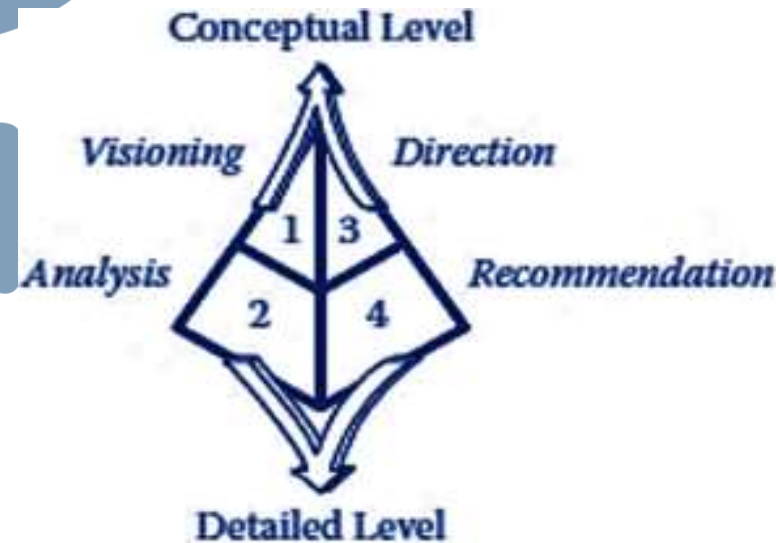

Gambar 9. Fase proses perencanaan ${ }^{[7]}$

\section{A. Fase penetapan Visi (Visioning)}

Pada tahap pertama Implementasi IT Master Plan adalah sangat penting untuk memahami, mengklarifikasi, dan mendokumentasikan arah bisnis termasuk mendokumentasikan: misi bisnis, visi, nilai, tujuan, sasaran, dan prioritas bisnis. Informasi tersebut didapatkan dari strategi bisnis dan dokumentasi serta melalui wawancara pihak eksekutif, seminar, dan survei atau melalui serangkaian percakapan interaktif.

Tugas utama fase Visioning ini adalah menganalisis dan mendokumentasikan dampak situasi bisnis terha- 
dap strategi SI seperti diuraikan pada gambar 10 dibawah ini:

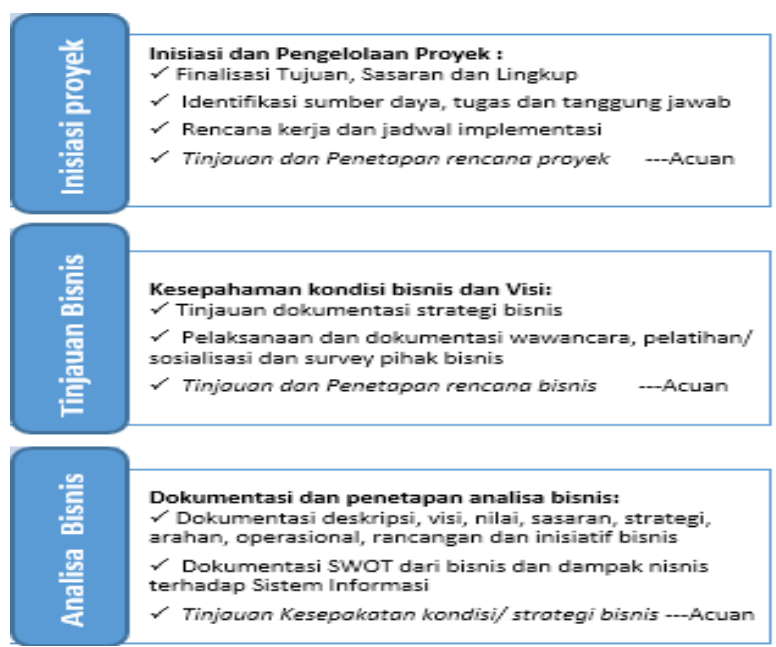

Gambar 10. Keluaran fase Visioning ${ }^{[7]}$

\section{B. Fase Analisis (Analysis)}

Fase analisis, melakukan analisa obyektivitas dan lingkungan SI secara meyeluruh yang memberikan pencerahan untuk mengkomunikasikan situasi SI kepada pihak manajemen eksekutif.

Secara obyektif fase - fase Analisis adalah menentukan dan mendokumentasikan kesenjangan/ gap dari lingkungan SI yang akan dituju di masa mendatang dibandingkan dengan lingkungan SI yang terjadi saat ini serta mengidentifikasikan SWOT (kekuatan, kelemahan, peluang, dan ancaman) kondisi SI sekarang pada masing-masing aspek aplikasi bisnis, infrastruktur teknis, organisasi, dan proses.

Hasil /keluaran dari Fase Analisis tersebut ini dapat mengidentifikasikan persyaratan utama terhadap pokok persyaratan informasi dan persyaratan bisnis, serta prosentasi pencapaian pemenuhanya oleh aplikasi bisnis saat ini sehingga dapat menentukan rekomendasi awal terhadap seluruh area SI yang masuk dalam arahan dan strategi SI yang akan diimplementasikan, seperti dijelaskan pada Gambar 11 berikut:

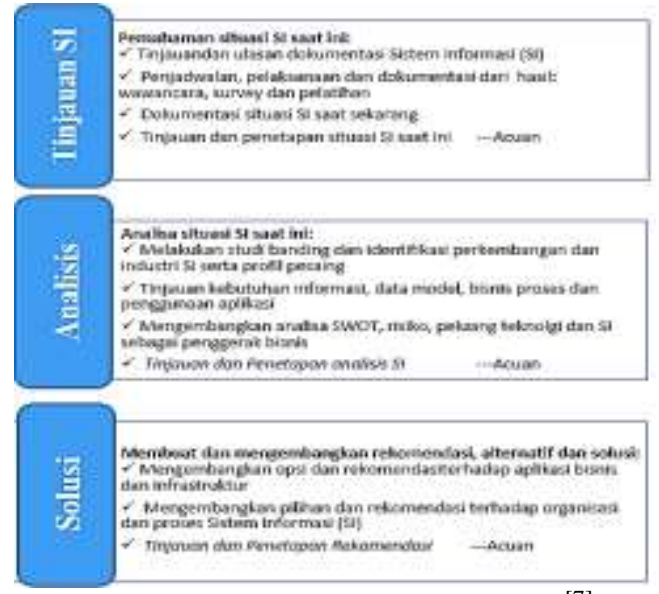

Gambar 11. Keluaran fase Analysis ${ }^{[7]}$

\section{Fase penetapan Tujuan (Direction)}

Fase penetapan Tujuan adalah merumuskan visi dan misi SI yang diartikulasikan menggunakan situasi dan arah bisnis sebagai dasar penetapannya. Merumuskan tujuan strategis SI yang diperlukan untuk membantu bisnis dalam mencapai tujuannya dengan menetapkan beberapa aspek detil dari setiap proyek implementasi SI yang direncanakan .

Langkah utama Strategi Informasi (SI) untuk menentukan cara terbaik dalam membantu bisnis mencapai setiap tujuannya adalah dengan cara perumusan pengukuran nilai atau kemajuan pencapaian/ performa SI secara berkelanjutan yang dijelaskan pada Gambar 12 dibawah ini :
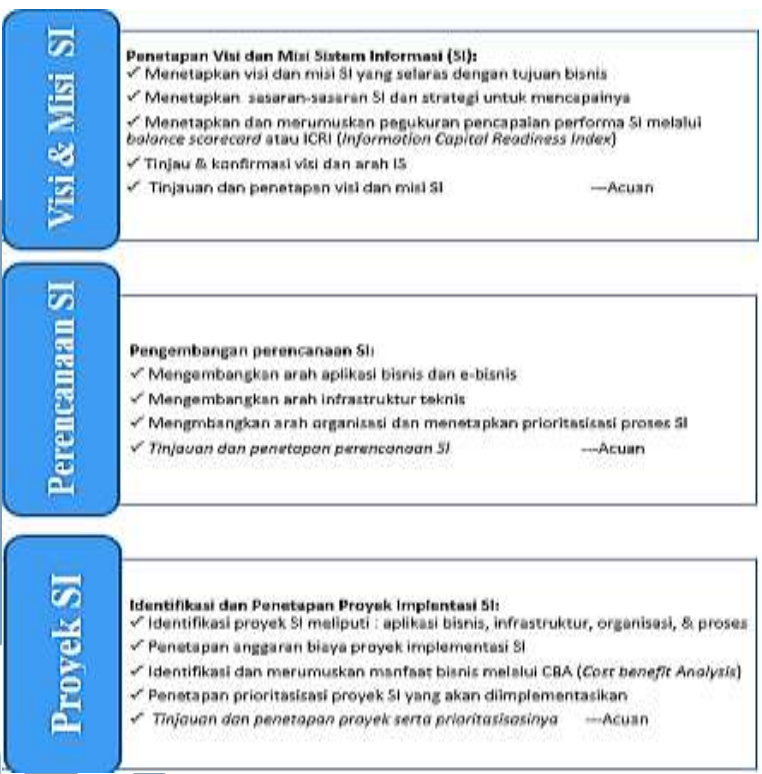
Gambar 12. Keluaran fase Direction ${ }^{[7]}$

Selanjutnya adalah menentukan detil proyek implementasi SI dan prioritasisasinya dari aplikasi bisnis yang direncanakan yang meliputi penetapan kebutuhan arsitektur komputasi teknis dan perubahannya yang mungkin terjadi serta menetapkan alokasi sumberdaya dan proses yang terlibat pada implementasi SI yang direncanakan.

\section{Fase Rekomendasi (Recommendation)}

Fase rekomendasi tersebut ini merupakan penetapan terhadap dokumentasi IT Master Plan yang direkomendasikan kepada manajemen organisasi untuk mendapatkan persetujuan pelaksanaannya untuk beberapa tahun ke depan dan berisikan rangkuman biaya, waktu, dan sumber daya yang diperlukan.

Penetapan dan dokumentasi IT Master Plan dilakukan melalui proses evaluasi dan studi banding dari pelbagai opsi solusi SI berdasarkan analisis laba atas investasi, risiko dan mitigasinya serta mengidentifikasi dampak organisasi yang terjadi seperti dijelaskan pada Gambar 13 berikut: 
Penerapan Beodines/ It Masser Phin:

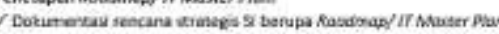

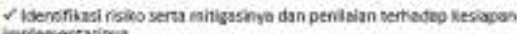
inperercasma

$\checkmark$ Tryauan dan peaesapan noodwop/ $\pi$ Mosrer Plar -Acusn

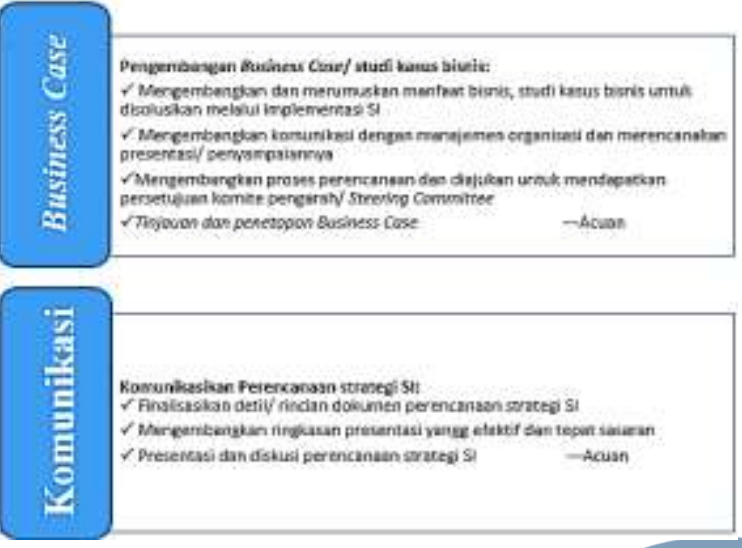

Gambar 13. Keluaran fase Recommendation ${ }^{[7]}$

Hasil/ keluaran yang didapatkan dari fase rekomendasi tersebut ini merupakan akhir dari proses perencanaan strategis SI (IT Master Plan) yang terdokumentasi dengan baik meliputi situasi bisnis dan SI yang dipahami dan mendapatkan dukungan seluruh unit kerja organisasi.

\section{KESIMPULAN}

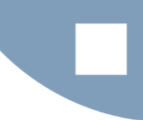

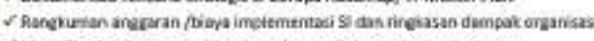

$\checkmark$ ibenentiasi den pentad an liesisoon

maka disampaikan hasil pemikiran penulis sebagai masukan dan usulan untuk penyelesaian terhadap kelemahan-kelemahan tersebut adalah dengan memprioritaskan beberapa pekerjaan dan aspek teknis berikut ini:

a) Menyusun perencanaan awal strategi TI yang dapat menjelaskan nilai/ manfaat yang dapat menghindari pengeluaran dan investasi TI yang tidak selaras dengan tujuan organisasi atau perusahaan seperti digambarkan pada gambar 3 .

b) Meningkatkan komunikasi yang efektif antara departemen bisnis dan SI sehingga implementasi dari IT Master Plan yang yang dilakukan flexible/adaptive dan tepat sasaran terhadap kebutuhan organisasi atau perusahaan.

c) Pada proses perencanaan dan tata kelola/ governance TI agar melibatkan semua tingkat bisnis dalam organisasi atau peursahaan dengan membentuk IT Steering Committee yang mewakili bisnis dan SI yang akan merumuskan rekomendasi mengenai prioritas proyek dan sumber daya dan menyediakan masukan ke arah strategis SI dan memastikan pihak Bisnis berkomitmen untuk memberikan manfaat bisnis dari proyek implementasi SI yang diselenggarakan.

Sehingga selanjutnya diharapkan IT Master Plan yang disusun dan diimplementasikan memenuhi beberapa kriteria strategi SI dan TI yang baik seperti:

Perkembangan bisnis yang pesat, didukung oleh perubahan teknologi yang tidak kalah cepat, menyebabkan perlunya penyelarasan yang kuat antara strategi bisnis atau organisasi dengan strategi strategi Teknologi Informasi (TI) dan Sistem Informasi (SI) sebagai pendukungnya. IT Master Plan (ITMP) sebagai rencana strategi TI dan SI yang mencakup banyak aspek, termasuk aspek arsitektur teknologi, perencanaan strategi dan proses untuk implementasinya, serta standar pendukungnya

Manfaat artikel penelitian tersebut ini adalah sebagai pedoman praktis dan referensi yang dapat digunakan untuk penyusunan dan implementasi IT Master Plan yang selaras dan mendukung pencapaian tujuan organisasi atau perusahaan.

Beberapa catatan penulis terhadap kelemahankelemahan Pengembangan IT Master Plan seperti yang disampaikan oleh Lembaga Riset Telematika Sharingvision[2] yaitu:

1) IT Master Plan yang kurang implementable,

2) Kurang mempertimbangkan aspek kelemahan kondisi lokal baik infrastruktur maupun kompetensi SDM

3) Kurang mendalamnya menangkap kebutuhan TI dari organisasi atau perusahaan
- Strategi Sistem Informasi dan Teknologi Informasi (SI/TI) yang mendukung pencapaian keunggulan kompetitif dari setiap peluang bisnis yang tercipta.

Strategi Sistem Informasi dan Teknologi Informasi (SI/TI) yang selaras dengan tujuan organisasi dalam rangka optimalisasi SI dan TI yang dapat memberikan kontribusi terbesar bagi organisasi.

- Strategi Sistem Informasi atau Teknologi Informasi (SI/TI) yang efektif (cost effective) dengan penerapan infrastruktur yang flexible/adaptive untuk kebutuhan pengembangan bisnis perusahaan ke depan.

Akhir kata, Penulis menyadari bahwa penulisan artikel penelitian tersebut ini masih terdapat kekurangan, baik dari aspek materi, sistematika penulisan, maupun dari aspek bahasa yang digunakan. Menjadi suatu kehormatan bagi penulis, terhadap semua saran perbaikan dan pembangunan untuk artikel penelitan ini, semoga artikel penelitian ini bermanfaat bagi penulis pada khususnya dan bagi pembaca pada umumnya. 


\section{DAFTAR PUSTAKA}

[1] ITGID Training, "Mengapa Perusahaan Membutuhkan IT Master Plan?", IT Governance Indonesia (ITGID), 17 November 2016, [Online]. Tersedia: https://itgid.org/trainingmaster-plan/ [Diakses: 15 Juli 2018].

[2] Sharing Vision, "Penyusunan dan Review Master Plan Teknologi Informasi", Sharingvision.com, 18 September 2014, [Online]. Tersedia: https://sharingvision.com/penyusunandan-review-master-plan-teknologi-informasi/ [Diakses: 15 Juli 2018].

[3] Arrianto Mukti Wibowo, Rifki Shihab, Budi Yuwono, Abdul Muthalib, Rein Nusa, M. Sattar, Suhendro, Dewi Puspa, Fitri, Rismawati Sunarya, Pusilkom UI," Rencana Strategis Teknologi Informasi \& Komunikasi 2011-2015”, Ringkasan Eksekutif, hal. 5, 6 Juli, 2011.

[4] Prof. Richardus Eko Indrajit, "Metodologi Penyusunan Rencana Induk (Master Plan) Sistem dan Teknologi Informasi Organisasi", Prosiding Konferensi Nasional Teknologi Informasi dan Komunikasi Indonesia, hal. 2, ITB 3-4 Mei, 2005.

[5] Alex Zverintsev Director, CIO Advisory Info-Tech Research Group, "Define an IT Strategy and Roadmap," Develop a data- driven, fit-for-purpose plan with a strong link to execution.", hal. 3-21, 10 Desember, 2015.

[6] Kementerian Komunikasi dan Informastika Republik Indonesia, "Master Plan Sistem Informasi", Dimensi Perencanaan, hal.13, 22 Feburari, 2012.

[7] Anita Cassidy, "Practical Guide to Information Systems Strategic Planning", 2nd ed Auerbach Publications, hal. 5,8,9,30,42,43,45,46,47, 2006.

[8] Nancy Lankton, CISA, CPA, Jean Price, "Board-level Information Technology Committees," ISACA Journal Volume 2, hal. 1-6, 2016.

[9] Alexander Zapata, CISA, CGEIT, CRISC, COBIT 5 Implementation and Assessor, ISO 22301 LI, ISO 27001 and Foundations, PMP, “Are Your IT and Strategic Business Goals Aligned?,” ISACA Article, hal. 1-2, 9 May 2016.

[10] Kementerian Badan Usaha Milik Negara Republik Indonesia, "Panduan Penyusunan Master Plan Teknologi Informasi BUMN", Lampiran II, Peraturan Menteri BUMN, Nomor: PER-02/MBU/2013, hal.1-14, 18 Feburari, 2013.
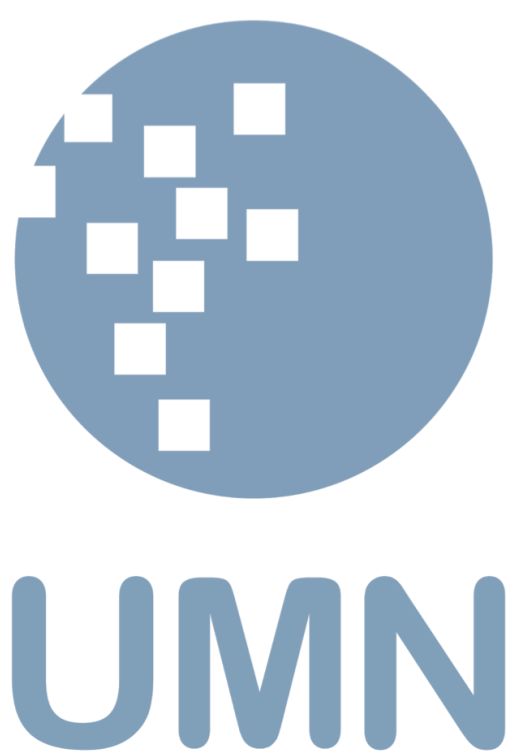